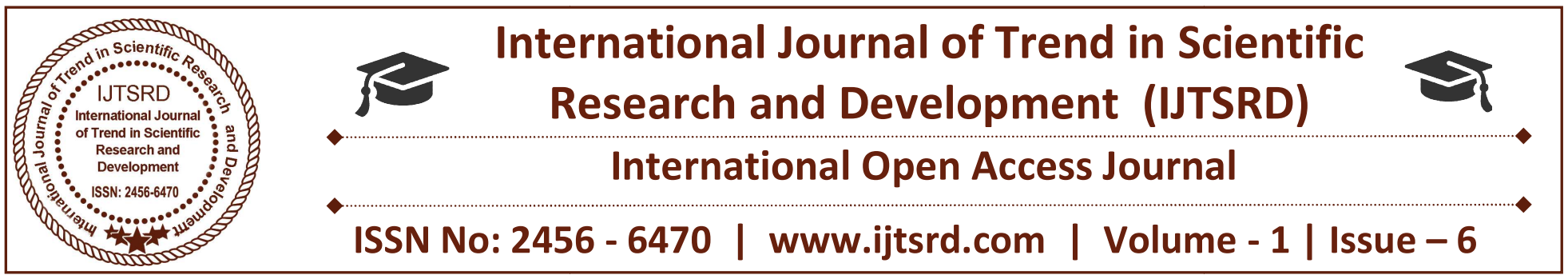

\title{
Role of MUDRA Yojana in Promotion of Financial Inclusion in Jharkhand
}

Sumit Kumar Gupta

Research Scholar, M com (UGCNET), Department of Commerce and Management, Vinoba Bhave University, Hazaribag
Kedar Nath Matho

Research Scholar, M com (UGCNET), Department of Commerce and Management, Vinoba Bhave University, Hazaribag
Niraj Dhar Dubey

Research Scholar, M com (UGCNET), Department of Commerce and Management, Vinoba Bhave

University, Hazaribag

\section{ABSTRACT}

Promotion of financial Inclusion is an important social and financial need of Indian Economy. In order to promote financial inclusion, recently, Govt. of India has launched several schemes like Prathan Mantri Jan Dhan Yojana,Prathan Mantri Jeevan Jyoti Bima Yojana, Prathan Mantri Suraksha Bima Yojana, Prathan Mantri Mudra Yojana, Atal pension Yojana, Varishtha Pension Bima Yojana, Started India schemes, financial Literacy schemes etc. Out of these, Prathan Mantri Mudra Yojana (PMMY) is one of the most important schemes of promotion of financial inclusion in India. Under this scheme, people can take loan up to Rs. 10 lakhs to start their businesses. This paper aims to highlights opportunity, benefits and performance of PMMY in India especially in Jharkhand.

Keywords: PMMY, MUDRA Bank, Financial Inclusion, MSMES

\section{INTRODUCTION}

Prathan Mantri MUDRA (Micro Unit of Development and Refinance Agency) Yojana is a potential step of promotion of financial inclusion in India. On $2^{\text {nd }}$ October, 2015 Hon'able Prime Minister shree Narendra Das Modi launched Mudra scheme in Dumka, Jharkhand. . However, It was originally launched on 8th April, 2015 by hon'able prime Minister Narendra Modi under the guideline of Department Of Financial services (GOI). Under PMMY, Micro Units Development and Refinance Agency Ltd. (MUDRA), a new institution has been setup by Government of India for development and refinancing activities relating to micro units . It was announced by hon'able Finance Minister 'Arun Jately' while presenting the Union Budget for FY 2015-16. MUDRA Ltd will monitor the progress of Prathan Mantri Mudra Yojna. Under this scheme, people can take three type of loan i.e. Loan upto Rs. 50,000 under Shishu; Rs. 50,000 to Rs. 5 lakh under Kishor; and Rs. 5 lakh to Rs. 10 lakh under Tarun. In F.Y.2016-17, 39701047 accounts has opened in India, out of these 1023593 accounts in Jharkhand in which total loan of Rs.175312.13 crore has disbursed in India out of these 3908.99 crore in Jharkhand. The Union Budget has announced a target of Rs. 2.44 lakh crore for Mudra Loans during 2017-18. At present, the scheme is applicable in all over India having 29 states and 7 union territories. The top three states getting biggest chunk of loan are tamilnadu, Karnataka, and Mahrastra. MUDRA Ltd will also refinance Micro-Finance Institutions through Pradhan Mantri Mudra Yojana. The top three institutions that received refinance under the MUDRA scheme are: SKS Microfinance, Ujjivan Financial Services Pvt Ltd, and Equitas Microfinance Pvt Ltd .

\section{OBJECTIVE OF STUDY}

1. To understand the meaning of MUDRA Yojana and MUDRA Bank

2. To study the objective and role of PMMY in India.

3. To analyze contribution of PMMY in promotion 
of financial Inclusion in Jharkhand.

\section{RESEARCH METHODOLOGY}

The study is based on secondary sources of data/ information. Different books, Economic survey, newspapers and relevant websites have been consulted in order to make the study an effective one. The study attempts to examine the performance and Importance of PMMY in India especially in Jharkhand.

\subsection{What is MUDRA Yojana:}

Pradhan Mantri Mudra Yojana (PMMY) was announced in the Union Budget for FY 2016 by Government of India for development and refinancing activities relating to micro units. The purpose of MUDRA is to provide funding to the non corporate small business sector that are currently engaged in a wide spectrum of economic activities like retail, manufacturing, trading etc.

\subsubsection{Product offered under PMMY}

1. Shishu:- This is targeted towards startups and sanctioned loan amount will be up to Rs. 50,000. The idea is to provide enough financial support to cover the expenses for business set up

2. Kishore:- This is targeted towards already existing businesses that lack exposure. The sanctioned loan amount will be between Rs.50000 and Rs 500000 . This scheme will help businesses to gain exposure by expanding their supply segment, which will in turn help to reach out to more customers

3. Tarun :- This is for those businesses which have grown to a certain level and have enough exposure but need help to take business to a new level. The sanctioned loan amount will be between Rs.500000 and Rs 1000000.

An essentially great feature of the MUDRA loan is that the loan amount is provided through the MUDRA Card (Rupay Card). The card is provided by the bank through which the loan is being sanctioned. The card can be utilized for different purposes like online payments, used as a Debit Card, and ATM card.

This would provide ease of payment and purchasing, and also encourage transparency in the business process. Moreover, the borrower needs to pay interest only on the amount of money that the borrower has used. Interest rates are dynamic and decided by the lending institution. A total of 27 public sector bank, 17 private sector Bank ,31 Regional Rural Bank, 4 Co-operative bank, 36 Micro Finance Institutions and 25 Non- banking Financial Institutions have currently been selected to allow disbursement of this loan.

\subsubsection{Benefits of Mudra Yojana:}

SC/ST enterprises and lending them for their startups

$>$ The lower income groups - helping them boost their small business

> To fund vendors, hawkers, self help groups, etc

$>$ To help those people access financial aid, who do not yet have bank accounts

$>$ Lower the cost of finance

$>$ Running a fair and square government micro credit scheme to boost self employment and small businesses

\subsection{What is MUDRA Bank:}

In order to implement scheme of PMMY effectively and successfully, MUDRA bank (Micro Units Development \& Refinance Agency) Ltd. was set up by the Government of India as a wholly owned subsidiary of Small Industries Development bank of India (SIDBI). It is for 'funding' the 'unfunded'. This will provide credit of up to Rs 10 lakh to small entrepreneurs and act as a regulator for 'MicroFinance Institutions' (MFIs) and Non-Banking finanace Company (NBFCs). Agriculture \& Selfemployment will be the focus areas of Mudra Bank.

\subsubsection{Objectives of the MUDRA Bank}

To encourage entrepreneurs and small business units to expand their capabilities and operations, to reduce over indebtedness and to provide formal system of credit.

System through regulation and inclusive participation.

To regulate the lender and the borrower of microfinance and bring stability to the microfinance to extend finance and credit support to Microfinance Institutions (MFI) and agencies that lend money to small businesses, retailers, self-help groups and individuals. 
To register all MFIs and introduce a system of performance rating and accreditation for the first time

$>$ To develop the standardized covenants that will form the backbone of the last-mile business in future.

To offer a Credit Guarantee scheme for providing guarantees to loans being offered to micro businesses.

To introduce appropriate technologies to assist in the process of efficient lending, borrowing and monitoring of distributed capital.

To build a suitable framework under the Pradhan Mantri MUDRA Yojana for developing an efficient last-mile credit delivery system to small and micro businesses.

\subsubsection{Responsibilities of Mudra Bank}

$>$ Laying down policy guidelines for micro/small enterprise financing business.

$>$ Registration and Regulation of MFI (MicroFinance Institutions) entities.

> Accreditation/rating of MFI entities.

To assist the lower income groups to develop and grow their small businesses.

To help in increasing the access of finance to the un-banked and to also bring down the cost of finance.

$>$ To provide access to Institutional Finance for Small Business Units (SBU).

$>$ Laying down responsible financing practices to prevent over indebtedness, ensuring client protection principles and methods of recovery.

$>$ Development of standardized covenants governing last mile lending to micro/small enterprises.

$>$ Formulating and running a credit guarantee scheme for providing guarantees to the loans which are being extended to micro-enterprises.

MUDRA bank will also be responsible for regulating and refinancing all micro-finance institutions (MFIs) which are in the business of lending to micro or small business entities engaged in manufacturing, trading and services activities.

To give priority to SC/ST enterprises in lending.

\subsubsection{Disadvantages and Points which are not clear in Mudra Banks:}

1. It is not cleared that whether the operation of Mudra Bank launched by PM Modi is under RBI supervision or not. If it is not controlled by RBI, than in future when it will grow then there will be potential risk of operation.

2. In present situation RBI is having control over all NBFC and Micro finance Institutions, but as the Mudra Bank is launched it will also regulate all Micro Finance Institutions. In This way Multi regulation will comes over Micro Finance Institutions. This will cause serious problems.

3. At present in India there are many Financial Intermediates that are already funding to small scale units at low Interest rate like National bank for Agriculture and Rural Development (NABARD), Small Industries Development Bank of India (SIDBI) and National Housing Bank (NHB).So it is not clear that how Mudra bank will differ from them \&why it is needed.

4. It is saying that it will act like a bank a give loan starting from Rs50,000/- to Rs 10,00,000/- and regulating Agency .That will cause serious problem when it grow in feature. It is not clear that whether it will work as bank or regulatory body.

5. To promote this system Govt will take the help of large Network of Post office. If they will use the Network of Post office to promote it will definitely increase the process timing of Loan distribution.

6. Till now it is not clear that what will be the process of getting the loan and how much time it take to clear the loan.

7. By the help of Mudra card you can make payment of only Rs 20,000/- .which is very low enough.

8. How the Portfolio Credit Guarantee will work it is not clear.

9. How Credit Enhancement will be there. 


\subsection{Role of MUDRA Yojana in promotion of financial inclusion in Jharkhand:}

\subsubsection{Jharkhand - An Overview:}

Jharkhand was formed on 15th November 2000, carving $46 \%$ land area with 18 districts from Bihar. The territory of this state is surrounded by the state of Bihar on the north, West Bengal on the east, Orissa on the south \& Chhattisgarh on the west. Jharkhand has some of the wealthiest deposits of iron \& coal in the world. It is also endowed with rich fauna \& flora. The state is abundantly endowed with mineral wealth, which probably no other state in the country can boast of. $33 \%$ of the country's coal reserves are in Jharkhand. However it is also among the poorer states in India. Population count as per 2011 census is 3.29 crs. Population has registered an increase of 60 lakhs in last 10 years i.e. from $2001-2011$. There is acute poverty and unemployment and with this trend of increase of population (i.e. 60 lakhs in 10 years), the problem will be grave. This region used to be once covered with thick dense forest, however massive deforestation has reduced the forest land to only about $28 \%$. Traditionally the forests were a major source of livelihood for the tribal but deforestation and rapid urbanization is having an adverse impact on their livelihood means. Due to increasing trend of population there is fragmentation of land holdings leading to decreasing availability of cultivable land per household. Paddy, millet and maize are the principal crops grown on small patches of land. The uncertainty of agricultural income has also resulted in migration to nearby States. Rural labour force cannot depend solely on agriculture for its livelihood. Hence the impetus for achieving sustained development in rural areas has to thrive upon expanding base of nonfarm activities like rope/ basket making, local handicrafts, puffed rice, poultry etc. The position shows that there is greater need of PMMY loan in the state.

\subsubsection{Contribution of PMMY loan in Jharkhand:}

Mudra scheme, in Jharkhand, nearly 1 lakh people have been provided with loans at first stage. Stressing on the development of tourism in the Santhal region, Modi initiated the renovation of Maluti temples in Dumka, inaugurated distribution of loans under the MUDRA Yojana and free LPG connections to families that are below poverty line in Jharkhand beginning with Dumka. The contribution of Mudra loan in context of Jharkhand in the F.Y.2016-17 can be explained with the help of following schedule:

Table 1

\begin{tabular}{|l|l|l|l|}
\hline Product & $\begin{array}{l}\text { No. of } \\
\text { loan a/c }\end{array}$ & $\begin{array}{l}\text { Sanction } \\
\text { Amount }\end{array}$ & $\begin{array}{l}\text { Disbursement } \\
\text { Amount }\end{array}$ \\
\hline Shishu & 969948 & 2176.08 & 2129.45 \\
\hline Kishore & 43689 & 1034.2 & 1006.65 \\
\hline Tarun & 9956 & 793.85 & 772.9 \\
\hline TOTAL & 1023593 & 4004.13 & 3908.99 \\
\hline
\end{tabular}

Source: www.mudra.org..in (compiled from State wise data)

Table 1 shows that no. of borrowers in Shishu Product is more in comparison to Kishore and Tarun. On the other hand sanction and disbursement amount in Shishu Product is also more in comparison to Kishore and Tarun. The comparative study between sanction amount and disbursement amount can be highlighted by following diagram:

\section{Figure -1 F.Y. 2016-17}

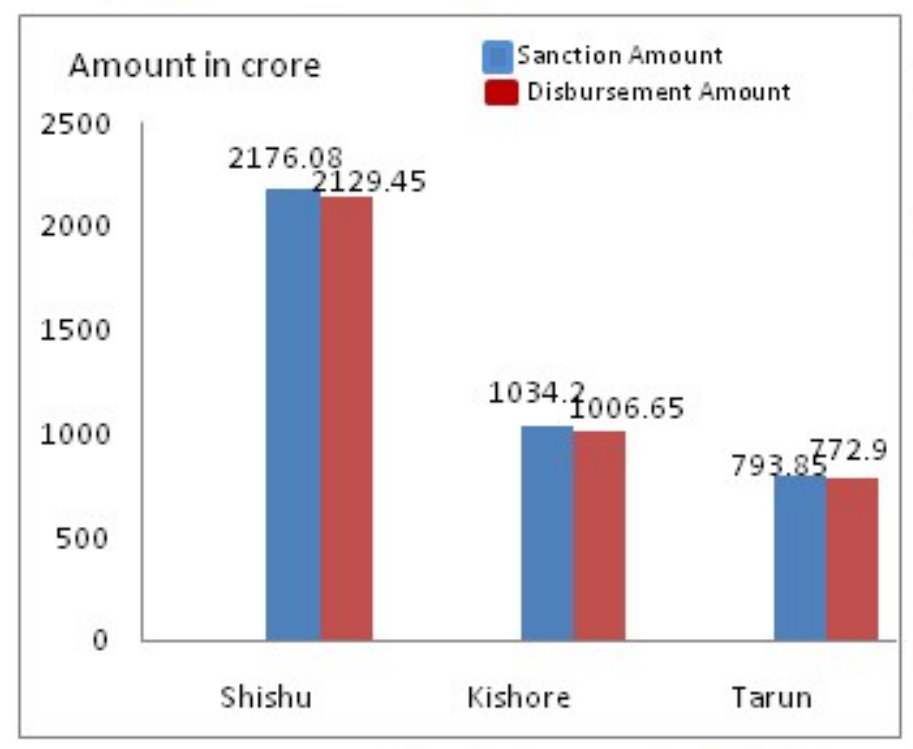

Figure 1 shows that sanction and disbursement amount of Shishu loan is more than Kishore and Tarun. Here, govt. wants to promote Shishu loan and help to micro entrepreneur. This can be explained with the help of following diagram:- 
Figure- 2

\section{Disbursement Amount}

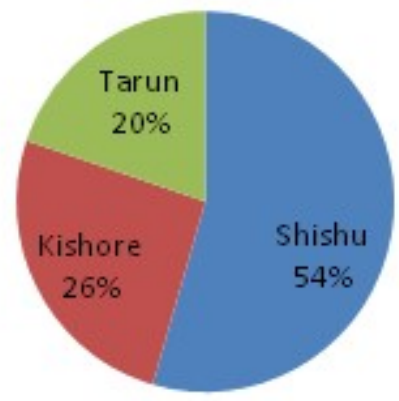

Figure- 2 shows that in F.Y. 2016-17, 95\% of numbers of borrowers are concerned with Shishu and rests are Kishore and Tarun. Similarly, as per figure$3,54 \%$ of disbursement amount has utilized in Shish, $26 \%$ in Kishore and $20 \%$ in Tarun.

Figure- 3

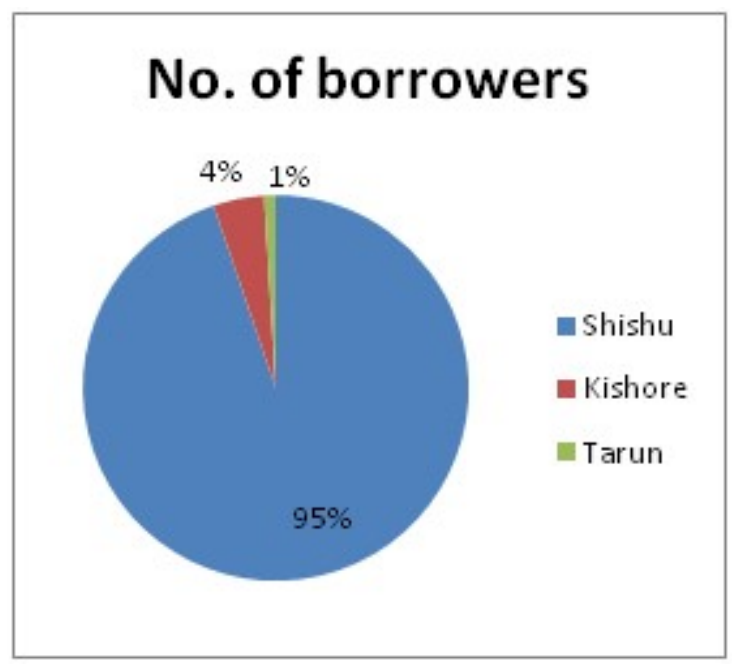

\section{CONCLUSION}

The small businesses form the foundation of the economic development needs to be strengthened and supported. A large number of Scheme have been taken in the past few years are a step in the right direction. MUDRA Yojana is the most recent scheme to boost up the small and micro business units in India. This scheme has been taken to focus exclusively on entrepreneurs. This type of scheme will add to the well-being of the individuals engaged in small scale industries which will positively shape the progress of the economy as a whole. MUDRA as a financial tool is found very effective in its early stages across the country. This will definitely make a dramatic change and will help in making a developed India

\section{REFERENCES}

1) Annual Report of PMMY 2016-17

2) Jharkhand Economic Survey 2016-17

3) Assocham India, Smera Ratings Limited. (2015). Small Business financing through MUDRA Bank - The Way forward Nurturing the start-ups for building the economy. New Delhi.

4) Benefits of Mudra Bank- How to Take Loan from Mudra Bank. (n.d.). Retrieved october 14, 2017

5) International Journal of Research in Economics and Social Sciences, 5(7), 185-191. Mudra Offerings, State wise PMMY Report.(n.d.).Retrieved October 20, 2017

6) PM launches MUDRA Bank to fund small businesses. (2015, April 9). Retrieved December 16, 2015, from business Standard Website:

7) PM launches MUDRA Bank to fund small businesses. (2015, April 9). New Delhi: Business Standard.

8) PM launches MUDRA Bank to fund small businesses. (2015,October 2 ).Dumka, Jharkhand ,from business standard websites

9) Venkatesh, J., \& Kumari, R. L. (2015, July). Performance of mudra bank: a study on financial assistance to msme sector.

10) Website: http://www.mudra.org.in/ 